\title{
Rozporuplný Arne Naess - několik poznámek k zakladateli hlubinné ekologie I.
}

\section{Bohuslav Binka}

Envigogika 2007/II/2 - Recenzované články/ Reviewed Papers

Publikováno/Published 31. 08. 2007

DOI: http://dx.doi.org/10.14712/18023061.16

\section{Abstrakt:}

Text zkoumá základní charakteristiky filosofického konceptu Arne Naesse, přibližuje jejich spojitost s osobností autora i vybranými rysy historického vývoje evropské kultury první poloviny 20. století a snaží se poukázat na jisté rozporuplné tendence Naessovy ekosofie $\mathrm{T}$.

\section{Klíčová slova:}

Hlubinná ekologie, Arne Naess, racionální, emocionální, vcítění se, pluralita, filosofická východiska, obsahová analýza, mentální mapa, ontologický dualismus

\section{Abstract:}

This text examines some basic characteristics of Arne Neass' philosophical concept, examines their connection with the authors' personality and selected outlines of historical development of European culture in the first half of 20th century and endeavors to refer to certain inconsistent tendencies of Neasses' ecosophy $\mathrm{T}$.

\section{Key words:}

Deep ecology, Arne Neass, rational, emotional, plurality, philosophical grounds, content analysis, mental map, ontological dualism 


\section{Úvod}

Cílem následující stati je prozkoumat základní charakteristiky filosofického konceptu Arne Naesse, ukázat jejich spojitost s osobností autora a vybranými rysy historického vývoje evropské kultury první poloviny 20. století, a konečně přibližit vliv zmíněného konceptu na vznik Naessovy hlubinné ekologie. Vedlejším cílem práce je pak prokázat, že filosofické základy, na kterých hlubinná ekologie Arne Naesse stojí, se zrodily dávno před jejím vznikem a jsou na ní samotné nezávislé. Stručně řečeno prokázat, že hlubinná ekologie je pouhým derivátem Naessova filosofického konceptu, nikoliv tímto konceptem samým. Struktura práce odpovídá takto určeným cílům. Nejprve krátce a kriticky přiblížím nejvýznamnější dosavadní interpretace Naessovy hlubinné ekologie. Následně se podívám na psychologické, sociální a historické okolnosti formování Naessova filosofického názoru a jeho filosofický vývoj jako takový. Nakonec se na rozboru tři vybraných textů Arne Naesse pokusím dokázat, že tyto vývody mají svoji podporu i v analýze textů samotného autora.

\section{Dosavadní interpretace filosofie Arne Naesse}

I v případě Arne Naesse, stejně jako u několika dalších pro environmentální hnutí významných autorů (Gándhí, Goldsmith), existují v zemích střední a východní Evropy dominantní, do jisté míry nepřesné a nedostatečnou sumou překladů ${ }^{1}$ podporované interpretace.

V první z nich, reprezentované v České republice ${ }^{2}$ zejména Erazimem Kohákem a Hanou Librovou, je Naess představen jako humanistický kritik současného směřování západní civilizace, čerpající u Koháka z Husserla a neprímo křestáanství, u Librové z východních nauk a neantropocentrického postoje A. Leopolda. ${ }^{3}$ Takto chápaný Naess pak stojí v príkrém protikladu k ostatním příslušníkům hlubinné ekologie (Devall, Sessions, Foreman, Seed, Macyová, Drengson).

Druhá interpretace, rozšířená zejména mezi hlubinně ekologickými autory, chápe Naesse jako zakladatele a centrální (i centristickou) postavu hlubinné ekologie a jeho názory jako trest' jejích postojů. ${ }^{4}$ Obě dvě interpretace jsou, podle mého názoru, v rozporu s některými fakty. Pokud by byl Arne Naess skutečně diametrálně odlišný od druhé a třetí generace hlubinných ekologů, jak naznačují Librová či Kohák, proč nikdy zásadním způsobem nekritizoval své následovníky a nástupce? Proč se za myšlenky Devalla, Seeda či Foremana dokonce vícekrát výslovně postavil? Proč byla jeho reakce na Bookchinovu kritiku hlubinné ekologie př́značně chladná?

\footnotetext{
1 V současnosti má čtenář k dispozici vynikající desetisvazkový výbor díla Arne Naesse. Viz Naess, A. The Selected Works of Arne Naess. Vyd. 1. Springer : Dordrecht, 2005.

${ }^{2}$ V Polsku zastupuje tuto interpretaci např. Henry Skolimowsky, v Rusku např. Victorie Levinská, která vychází z vlastních ruských "hlubinně ekologických" zdrojů - převážně konzervativní křestáanské provenience (V. Vernadskij, N. Rerich, P. Florenskij). Viz Skolimowski, H. Living Philosophy: Eco-Philosophy as a Tree of Life. Vyd. 1. London : Arkana 1992. Levinská, V. Place of Ecological Culture in the Civil Society. Př́spěvek konference Restorying the Police ve Washingtonu, D. C. 1998.

${ }^{3}$ Viz Librová, H. Pestří a zelení: Kapitoly o dobrovolné skromnosti. Vyd. 1. Brno : Veronica 1994. $\mathrm{Na}$ stránkách 164-167 a 172-174 Librová klade Naesse a jeho koncept ztotožnění do protikladu k Reedově koncepci „odděleného člověka".

4 Takto chápou Naesse téměř všichni píšící autoři hlubinné ekologie. A takto interpretuje sám sebe i Naess - jak uvidíme dále. Uved'me jen několik příkladů: Fox, W. Arne Naess: A Biographical Sketch. The Trumpeter, 1992, roč. 9, č. 2; Drengson, A. The Deep Ecology Movement. The Trumpeter, 1995, roč. 12, č. 3; Seed, J. Uslyšet v sobě hlas plačící Země. In Myslet jako hora. Prešov, Abies 1993, s. $12-13$.
} 
A na druhou stranu, pokud by skutečně hlubinná ekologie Arne Naesse znamenala jediný správný hlubinně ekologický výklad - jak naznačuje většina hlubinně ekologických autorů - proč Naess tak často zdơrazňoval, že si každý má vytvořit svoji vlastní hlubinnou ekologii a jeho je pouze jedním z květů? Jak by mohl být A. Naess centrální postavou hlubinné ekologie, když celé jeho hlubinně ekologické dílo popírá možnost jednoho, centrálního výkladu? Zdá se, že hlubinní ekologové druhé generace (B. Devall, G. Sessions či J. Seed) oceňují na díle Arne Naesse mimo jiné rys (objev univerzálního kritéria pravdivosti a jisté výlučné metapravdy), který je Naessově filosofii ve skutečnosti minimálně částečně cizí.

Jak vidíme, obě dosavadní interpretace naráží na značné potíže.

\section{Historicko-filosofický exkurz}

Přestože analýzu Naessovy filosofie a hlubinné ekologie postavím v první řadě na rozboru Naessových textů, bude z hlediska českého čtenáře př́nosné zahájit práci krátkým historicko-filosofickým a následně psychologickým exkursem. Ten totiž mnohé z rozporuplných dojmů z četby textů Arne Naesse přinejmenším naznačí. Protože k tomuto úkolu přistupuji již s určitou znalostí Naessovy životní dráhy i jeho textů - a obojí potvrzuje ${ }^{5}$ můj předpoklad o výrazné rozporuplnosti Naessova díla - budu se snažit o vystopování tendencí, a jejich historické posloupnosti, které Naessovu rozporuplnost objasní.

Abychom pochopili Naessovu osobnost a Naessovo dílo, je potřeba samotného autora zasadit do jistého kulturně-sociálního a psychologického kontextu. A protože Naess, sledující svůj velký vzor M. Gándhího, netají ze svého života téměř nic a zároveň existuje (samozřejmě mimo území České republiky) dostatek sekundárních zdrojů o Naessově osobním i filosofickém vývoji, není taková charakteristika jeho osobnostního vývoje nemožná. 6

Začněme krátkým historicko-filosofickým exkurzem. Naess začíná svojí filosofickou dráhu u norských myslitelů Heralda Hoffdinga a Andrease Winsnese, ${ }^{7}$ kteří reprezentují pouhou derivaci tehdejších německých myslitelů. Záhy však odchází do Vídně, kde zpočátku navštěvuje především tzv. Vídeňský kruh (setkává se zde a je ovlivněn

5 Nebot' jak sloučit Naessův příklon k Vídeňskému kruhu a současný obdiv k Heideggerovi, jak vysvětlit Naessův koncept „Ekologického Já" v protikladu k osobnímu já, ve kterém Naess jednoznačně stojí na straně odosobněného Já a jeho - bytostně západní - touze po stále rostoucí diverzitě. Jeho Gándhíovsky lhostejné přijetí nacistických okupantů a následnou dưslednou rezistenci? 6 . V následující pasáži budu vycházet především z knihy rozhovorů Davida Rothenberga a Arne Naesse Is It Painful to Think?, což samozřejmě neznamená, že další důležité zdroje neexistují. Nicméně texty G. Sessionse - např. úvodní slovo k Naessově kapitole v knize Sessions, G. Deep Ecology for the 21st Century: Reading on the Philosophy and the Practice of New Environmentalism. Vyd. 1. Boston : Shambhala, 1995, s. 187-194; Alana Drengsona - článek Drengson, A. The Deep Ecology Movement. The Trumpeter, 1995, roč. 12, č. 3; či Richarda Langlaise -Langlais, R. Living in the World: Mountain Humility, Great Humility. In Deep Ecology for the 21 st Century: Reading on the Philosophy and the Practice of New Environmentalism. Boston : Shambhala, 1995, s. 195-203 mi připadají příliš obdivné a nekritické na to, abychom je mohli použít. Několik příkladů. Všichni uvádí Naessovy úspěchy - dosažení profesury ve 27 letech, získání Sonningenovy ceny v roce 1977, sepsání 30 knih (což mimochodem není pravda), ale vůbec se nezmiňují o problematických pasážích Naessova života - např. první měsíce německé okupace, jeho chování k první ženě, jeho "odmítnutí Západu”. Takové zdroje jsou pak sice nikoliv bezcenné, ale spíše nepoužitelné. Sessionsovo rozdělení Naessova díla v hlubinně ekologickém období - tzn. mezi léty 1972-2001 na "1972 - Bukurešt́ská přednáška", "Ekosofie T" a "1984 - hlubinně ekologická platforma" je navíc značně umělé. Stačí porovnat texty z počátku Naessovy hlubinně ekologické dráhy $s$ texty pozdějšími. Rozdíly $v$ ontologických východiscích, střední analýze textů i logické konzistenci neexistují.

7 Viz Naess, A., Rothenberg, D. Is It Painful to Think?: Conversations with Arne Naess. Vyd. 1. London

: University of Minnesota Press, 1993, s. 11-12. 
především Rudolfem Carnapem, Moritzem Schlickem a Friedrichem Waismannem) a přijímá - jeho vlastními slovy - sdílený anti-fašismus, anti-nacionalismus a antimaterialismus, a zejména pak metodu nepřímého boje s těmito nebezpečími. ${ }^{8}$ Dưraz členů kroužku na "odstraňování filosofického balastu" však neuspokojuje jeho touhu po radikálně novém, návrat k barbarství znemožňujícím výkladu světa. Proto se obrací, prostřednictvím Dr. E. Hitschmana, ${ }^{9}$ k psychoanalýze, které se věnuje více než půl roku. Ani psychoanalýza však jeho nárok na zásadní reformu "západní kultury a civilizace" nesplní a tak odjíždí roku 1938 do Spojených států, kde začíná, nikoliv ovšem ve smyslu materiálním, naprosto od začátku. Odhazuje ještě před rokem či dvěma hájený filosofický balast a obrací se jednak na "striktně vědecký behaviorismus" v podání právě začínající empirické psychologie, 10 jednak na zkoumání názorù „prostých a obyčejných" lidí. Řečeno zkratkou, utíká od filosofie představující řešení krize „západní kultury” k vědě a obyčejným lidem. Ani tento obrat však není definitivní. Na striktním behaviorismu založené pokusy s krysami sice Naesse natrvalo ovlivní, ale postupem času začíná pochybovat o jejich použitelnosti pro jeho prvořadý a základní cíl. Nakonec od intenzivního pokračování v těchto výzkumech odstoupí. Významně Naesse ovlivní i rok 1968,11 když po nějakém čase odmítne neo-marxistické představy a přihlásí se znovu k dvěma odlišným autorům: $M$. Gándhímu a B. Spinozovi. Od počátku 70. let je Naess proměněným autorem. Žádný další vývoj, žádné další významné filosofické koncepty. Od této chvíle budou u Naesse převažovat obhajobné články, reakce na kritiku jím vytvořené hlubinné ekologie a apologetika ostatních hlubinně ekologických autorů. Když Naess píše svůj první "hlubinně ekologický" článek, ${ }^{12}$ jsou výchozí body jeho filosofie dávno ustálené, pevné, neměnné. Jaké vlivy v popsaném životě plném hledání utvořily Naessův filosofický koncept a jeho hlubinnou ekologii?

Vidím tři, přičemž první je spjat s charakterovým typem samotného autora - a je z tohoto hlediska nejméně důležitý - druhé dva pak s výrazným vlivem vnějším.

Naess vyrůstal $v$ relativně bohaté přísně protestantské rodině. Jeho rodiče (otec zemřel, když byly Naessovi méně než dva roky), a zejména matka nehodlali dítě rozmazlovat - a rozmazlováním se v tomto kulturním prostředí chápala vlastně jakákoliv emocionálně podmíněná a emoce obsahující péče. Nakonec mu byla „přidělena" vlastní chůva. ${ }^{13}$ Ta se Naessovi, podle jeho vlastních slov, stala novou matkou, rozmazlující a obětavou. Právě kvůli citové vazbě (Naess nenachází žádný jiný možný důvod) však Mina musela rodinu opustit a Naess se $s$ touto ztrátou bytosti, kterou miloval, nikdy nesmíril. Jak sám píše, od té doby nedokázal někoho milovat a snažil se nespecifikovat svou lásku na konkrétní osobu, ale „milovat vše, naprosto, úplně vše". ${ }^{14}$ Tento rys, který Naess označuje př́značně freudiánským (či přesněji řečeno reichiánským) termínem „Panzercharakter", tvoří podstatnou podmínku jeho nakonec ustáleného světonázoru.

\footnotetext{
${ }^{8}$ Viz Naess, A., Rothenberg, D. Is It Painful to Think?: Conversations with Arne Naess. Vyd. 1. London : University of Minnesota Press, 1993, s. 13-29.

9 Viz Naess, A., Rothenberg, D. Is It Painful to Think?: Conversations with Arne Naess. Vyd. 1. London : University of Minnesota Press, 1993, s. 31, 34-35, 37-38.

${ }^{10} \mathrm{~V}$ podání tehdejšího průkopníka E. C. Tolmana.

${ }^{11}$ Důkazem Naessovy upř́mnosti jsou i na více místech popisované zkušenosti S LSD - které mimo jiné distribuoval (čehož dnes lituje). Viz např. Naess, A., Rothenberg, D. Is It Painful to Think?: Conversations with Arne Naess. Vyd. 1. London : University of Minnesota Press, 1993, s. 53-55.

12 Stalo se tak roku 1973 v jím redigovaném časopise Inquire. Viz Naess, A. The Shallow and the Deep, Long-Range Ecology Movement: A Summary. In Deep Ecology for the 21st Century: Reading on the Philosophy and the Practice of New Environmentalism. Vyd. 1. Boston : Shambhala, 1995. s. 151155.

13 Jmenovala se Mina a Naess se s ní po jejím nuceném odchodu již nikdy neměl možnost vidět. Viz Naess, A., Rothenberg, D. Is It Painful to Think?: Conversations with Arne Naess. Vyd. 1. London: University of Minnesota Press, 1993, s. 3-10.

14 Viz Naess, A., Rothenberg, D. Is It Painful to Think?: Conversations with Arne Naess. Vyd.

1. London : University of Minnesota Press, 1993, s. 3-10.
} 
Druhý vliv je spojený, jak bylo řečeno výše, s Naessovým zklamáním z první, a zejména druhé světové války a $z$ "krize evropské kultury". ${ }^{15}$ Naess se nedokázal smírit s fragmentárností evropské vědy, s absencí "ústředního" projektu, s trvalou „částečnostî" filosofie 20. století. Stejně jako nedokázal milovat jednotlivou bytost a raději miloval vše, stejně jako odmítal dualismus ve jménu "Jednoho", tak nedokázal přijmout žádnou jednotlivou filosofickou nauku (logický pozitivizmus, psychoanalýzu, behaviorismus, neomarxismus) a přitom o nalezení jedné, definitivní nauky usiloval. Východiskem se mu stali nakonec M. Heidegger, ${ }^{16} \mathrm{P}$. Zapff, ${ }^{17}$ a konečně M. Gándhí. ${ }^{18}$ Proč právě oni? Všichni tři mají několik shodných rysư. Kritizují „moderní společnost” a usilují19 o jistou formu návratu. Návratu k "civilizaci ducha" (Gándhí), ke "krvi a půdě" (Heidegger), k "životu nevědomému" (Zapff). Všichni tři jsou autoři prosazující více dojem, impresi, intuitivní pocit z textu než zřejmost, jasnost, srozumitelnost, čímž Naessovi umožňují, ačkoliv každý jiným způsobem, zưstat u jejich přesvědčení, protože si je může vždy definovat jinak. A konečně všichni tři usilují o "konec dualismu" a jeho nahrazení ontologickým realismem. Všichni tři jsou z těchto hledisek proti-západní, proti-osvícenští a proti-racionalističtí. Naess se k tomuto řešení krize filosofie a evropské kultury, tak jak jí poznal v Norsku i ve Vídni, přikláněl již od 30. let. Vše nasvědčuje tomu, že kolem roku 1935-1937 byl rozhodnut a vše další - např́klad jeho odjezd do USA, jeho opětovné koketování s psychoanalýzou, jeho trvalý zájem o Spinozu - můžeme považovat za otvírání zadních vrátek něčemu, co bylo natrvalo vykázáno a nahrazeno sublimátem Gándhího, Heideggera a Zapffa. Po druhé světové válce - kterou mimochodem zpočátku považoval za spíše nevýznamnou a zkreslující skutečnou krizi evropské civilizace - je rozhodnuto a pro Naesse bude cokoliv spojené s racionalitou, osvícenstvím a "tímto světem" hrát vždy jen "druhé housle" ve prospěch ne-racionálního, hlubinného a "skutečného". To, co mate čtenáře Naessových textů (a autora této práce také) je silný spodní proud, silné protikladné působení, které na rozdíl od Gándhího nedovolí Naessovi úplně opustit jisté postoje příznačné pro naši kulturu.

A jsme u samého jádra Naessova problému. Naess by vědomě na rozcestí Gándhí versus Popper, Husserl versus Heidegger, východ versus západ, tento svět versus onen svět volil vždy proti Popperovi, Husserlovi, západu a tomuto světu, ale vlastní mentální mapou ke Gándhímu ${ }^{20}$ nepatří. Nedokáže „jedinou pravdu“ hájit přesvědčivě, a to proto, že

\footnotetext{
${ }^{15}$ Naess tento termín několikrát použil. Husserlovo dílo samozřejmě velmi dobře znal.

${ }^{16} \mathrm{Na}$ Heideggera se Naess neodvolává dlouhými pasážemi (kromě knihy přímo věnované - mimo další tři filosofy - Heideggerovi), nicmémě jeho silné ovlivnění je mimo pochyby - viz např. Naess, A. Heidegger, Postmodern Theory and Deep Ecology. In The Trumpeter, 1997, roč. 14, č. 4. (do hlubinné ekologie mě umístil Heidegger), či Naess, A., Rothenberg, D. Is It Painful to Think?: Conversations with Arne Naess. Vyd. 1. London : University of Minnesota Press, 1993, s. 26.

17 Vliv významného norského filosofa, anti-křest́ana a "striktního pesimisty" je dosud nedoceněn. Naess mu věnuje ve svém životopisném díle více prostoru než Spinozovi i Gándhímu, Zapffưv odpor k životu jako skutečnosti, která stojí za námahu, však Naess transformoval do velmi zvláštního a Gándhímu podobnému dualismu našeho osobního života a velkého Já.

18 Gándhí je asi nevýznamnějším impulzem ke vzniku filosofie a následně pak i hlubinné ekologie A. Naesse. Gándhí představuje - a to věrně - svět, ke kterému se Naess nakonec obrátil. Vliv Gándhího můžeme doložit následujícími články a knihami: Naess, A. Gándhí and the Nuclear Age. Vyd. 1. Totowa : Bedminister, 1965; Naess, A. Gándhí and Groupe Conflict: An Exploration of Satyagraha Theoretical Background. Vyd. 1. Oslo : Universitetsforlaget, 1974; Naess, A. The Three Great Movements. The Trumpeter, 1992, roč. 9, s. 2; Naess, A. Sebeuskutečnění: ekologický přístup k bytí ve světě. In Myslet jako hora: Shromáždění všech bytostí. Vyd. 1. Prešov : Abies 1993; Naess, A. Deep Ecology in the Line of Fire. The Trumpeter, 1995, roč. 12, č. 3. Naess cituje Gándhího ve většině svých článků, zde jsme vybrali jen ty, kde se Gándhímu věnuje podrobněji a i tento výběr je neúplný.

${ }^{19}$ Nejproblematičtější je to u Zapffa, ale i on má ve svém díle koncepci "návratu".

20 Nemám zde bohužel dostatek prostoru pro rozbor díla M. Gándhího. Musím proto bez další argumentace konstatovat, že dílo M. K. Gándhího je v evropském prostředí dlouhodobě přinejmenším od druhého desetiletí minulého století - spojeno s neodpustitelnou, i když velmi snadno pochopitelnou dezinterpretací. Lidé jako R. Rolland, A. Einstein či M. Bureau, na které velmi těžce dolehl vývoj západní Evropy v první polovině 20. století, přivítali Gándhího a zejména jeho mimořádný politický úspěch jako "nové světlo", naději pro celý svět či "dobro podavší nám ruku z daleké Indie".
} 
„jedinou pravdu" svojí mentální mapou drolí, narušuje, podlamuje. Mưže psát o ekologickém Já, ale to, jak píše, vylučuje nárok na absolutní, fanatické, fundamentalistické. Př́liš dlouho nechával skrze Vídeňský kruh, Freuda či Tolmana otevřená zadní dvířka dědicưm osvícenství na to, aby se mohl stát „novým fundamentalistou" se vším všudy. ${ }^{21}$

Z tohoto hlediska je následný Naessův "vývoj" po vzniku hlubinné ekologie, a zejména po jeho definitivním vítězství v boji o ekologický diskurs, které Ize umístit do počátku 80. let, nezajímavý. Jak Ize dokumentovat na jeho příspěvcích do sborníků hlubinné ekologie té doby (1976-2002) či na jeho časopiseckých příspěvcích, Naess od konce sedmdesátých let nemá žádný vnitřní ani vnější vývoj. Prosazuje mnohost alternativ, ale pevně si stojí za dávno přijatým světonázorem i mentální mapou své osobnosti. Tzv. převratné články jako Mountains and Mythology, 22 či na druhou stranu „proti-hlubinný" článek „The World of Concrete Contents"23 jsou jen stř́dáním dikce, nikoliv skutečnou změnou Naessova světonázoru. ${ }^{24}$ Žádnou změnu postoje nepřinesl ani

A at již vědomě (Tolstoj, Bureau, později Huxley) či nevědomě (Einstein, Rolland, Zweig) Gándhího interpretovali jako jakýsi vyšší stupeň evropského humanismu, pravého náboženství a lásky k člověku. Trestí této interpretace je i známý film, který překrásně vykreslil Rollandova Gándhího, ale o skutečném Gándhím nám toho neřekl, kromě falešně interpretovaných pravdivých historických faktů, mnoho. A přitom je jen málo myslitelů tak přistupných, nic neskrývajících a svojí naukou doslova průhledných. Gándhí je tedy především dưsledným náboženským a anti-humanistickým myslitelem. Jeho na první pohled nesmysIné činy - riskování života své nemocné ženy a dětí zapovězením západních léků a lékařù, odmítání aktivní obrany Indie proti japonské agresi, prudký odpor vưči zavedení železnice, vysokých škol či nemocnic v Indii, prosazování nevařené stravy přes naprostý neúspěch experimentu se svým vlastním stravováním - jsou v logice náboženskyfundamentalistického postoje hluboce smysluplné. Pro Gándhího je prostě spása ducha svým významem neporovnatelná $s$ hodnotou pozemského života a štěstí. Vše, co směřuje $k$ životu vezdejšímu je bezcenné a vše, co směřuje k životu nadpozemskému, má absolutní hodnotu. Toto východisko nalezneme ve většině Gándhího knih a článků. Jako jeden z prvních na Gándhího náboženský fundamentalismus upozornil George Orwell ve své vynikající stati - viz. Orwell, G. Uvnitř velryby a jiné eseje. Vyd. 1. Brno : Atlantis, 1997, s. 477-484.

${ }^{21}$ Jak Ize charakterizovat pojem nový fundamentalismus? Mezi jeho základní rysy patří ambivalentní vztah k moderní společnosti, kterou stejně jako tradiční konzervativizmus pohrdá, ale na rozdíl od něj se jí neštítí a bez nejmenšího zaváhání dokáže využít všech jejích technických i společenských výdobytků. Kritizuje její rozdrobenost, anomii a absenci celkového projektu, ale dokáže se honosit doktoráty z jejích univerzit a ve své argumentaci s úspěchem využívá autority "zbloudilé" vědy. Modernost není podle něj schopna vytvářet hodnoty, ale je docela dobře možné využít její utopickou terminologii. Není ani totalitarismem, přestože s ním sdílí jeho nárok na absolutní ovládnutí, jeho Ihostejnost $k$ realitě a také jeho podivnou formu utilitarizmu, protože většina novým fundamentalismem prostoupených organizací funguje na základě dobrovolnosti a demokracie. Lidé jako Jim Barkker, Sajjid Kutba či Máhátma Gándhí věři v platónskou ideu Dobra, Krásy a Lásky, ale na rozdíl od klasických konzervativních fundamentalistů nepovažují za nemravné získávat pro tuto čistou ideu ostatní těmi nejnemravnějšími zbraněmi, které dokázala jimi nenáviděná moderní společnost vyvinout. Jazyk a způsob myšlení public-relations, tedy zosobněný princip neúcty ke světu, který nahližíme jako předmět hodný jedině sobecké manipulace, se spojuje s fanatismem vnější pravdy, jíž jsme služebníci. Výsledkem je vskutku nová, fundamentálně povrchní i povrchně fundamentální dábelská směs, a at́ už má podobu islámského, židovského, katolického či ekologického fanatismu, mají se všichni, kteří chovají v úctě rozum, ironii, odstup, úctu, logiku či demokracii, čeho bát.

22, Neobvyklý článek z roku 1995, který Naesse přibližuje k hlubinným ekologưm typu Seeda či Abbeye. Ale i zde - přestože článek je velmi krátký a relativně konzistentní - najdeme místa vracející Naesse směrem k liberálním, nefundamentalistickým názorům. Viz Naess. A. Mountains and Mythology. The Trumpeter, 1995, roč. 12, č. 4.

${ }^{23}$ Zde naopak Naess výrazně přesouvá zřetel k analytickému, dekonstruktivnímu přistupu. Ovšem svou realistickou ontologii nemíní opustit ani na okamžik. Dekonstruovat dokáže Naess skvěle, ovšem dekonstrukci $v$ př́padě jistých oblastí nepřipouští. Ani tady nejde o Naessovu proměnu, či revoluční změnu jeho názorù. Jde jen o jiný předmět zájmu a mírně pozměněnou dikci. Viz Naess, $A$. The World of Concrete Contents. Inquiry 1985, roč. 28, s. 417-428.

${ }^{24}$ Samozřejmě existují i jiné názory - Sessions např́klad klade zlomové prvky Naessova vývoje do jiných souvislostí - podle vědeckého zájmu Naesse - ovšem toto dělení je podle mého názoru vedeno 
pro hlubinnou ekologii tak důležitý rok 1987, ve kterém Murray Bookchin dramatickým způsobem odpadl od hlubinné ekologie a proměnil tak význam samotného slova. Naessova reakce byla přiznačná. V žádném případě se nepostavil proti „misantropickým” hlubinným ekologům, ale také jeho kritika Bookchina byla přinejmenším vlažná. ${ }^{25}$ Celá roztržka ho nechala $v$ podstatě chladným. Stručně řečeno: Hlubinná ekologie Arne Naesse není (ve vývoji jeho filosofických názorů) něčím novým, převratným, ale naopak stává se logickým vyústěním Naessových postojů přijatých dříve, než hlubinná ekologie vzniká. ${ }^{26}$ Zároveň se vlastní Naessova verze hlubinné ekologie, tzv. Ekosofie T, od počátku svého vzniku nevyvíjí a až do dnešního dne s sebou nese obě tendence Naessova postoje. Rozpačitost spojená s Naessovým dílem je produktem právě těchto tendencí a inertnosti Naessových postojů.

\section{Naessova filosofická východiska a hlubinná ekologie}

A po stručném historickém výkladu mohu začít s rozborem Naessova díla. Naessova hlubinná ekologie tedy vzniká jako odpověd' na selhání moderny a západní civilizace vủbec, $^{27}$ a to odpověd' sekundární, druhotná, dlouho poté co Naess vlastní, osobitou filosofii vytvořil. Jak hlubinnou ekologii charakterizovat?

Především odmítnutím dualismu, který stojí na antropocentrických základech a uznáním jednoty všeho živého i neživého. Tím se Naess vlastními slovy ${ }^{28}$ liší od ostatních ekologicky orientovaných autorů. Ti kladením důrazu na nutnost omezení svého vlastního já nemohou dlouhodobě přesvědčit ostatní obyvatele Země ke změně životního stylu. Naess usiluje o změnu nazírání světa, nikoliv o změnu v oblasti etiky. Usiluje o novou, nedualistickou a zároveň realistickou ontologii. ${ }^{29}$ Jinými slovy, odmítá klasickou představu člověka $v$ přírodě, představu individuálního, materiálně vymezeného já a tu nahrazuje představou Já s velkým „J", Já, které je, ač hierarchizováno, jednotné a jediné a jehož význam je shodný s významem slova átmán v Gándhího textech. ${ }^{30}$ Toto široké Já, které se rozvíjí od sociálního Já k ekologickému Já až na pomezí metafyzického Já, postupně zahrnuje další a další bytosti, celé ekosystémy a nakonec svět. $V$ tomto konceptu je podle Naesse nutné uznat naprostou rovnost všeho živého, která plyne z naší závislosti na hlubokém uspokojení, jež čerpáme z jednoty s ostatními životními formami. Stejně jako

spíše snahou postavit Naesse na piedestal, nikoliv podat skutečně zlomová místa jeho vývoje. Viz Sessions, G. Deep Ecology for the 21st Century: Reading on the Philosophy and the Practice of New Environmentalism. Boston : Shambhala, 1995, s. 185-261.

25 V červnu roku 1987 vystoupil na konferenci American Green Activist s ostrou kritikou hlubinné ekologie Murray Bookchin. Ovšem ani Bookchinův velmi tvrdý a téměř agresivní atak nevyvolal u Naesse žádné změny. Spor mezi sociální a hlubinnou ekologií, ve kterém proti sobě stáli Bookchin, Chodorkoff, Biehl a Forman, Abbey či Manes sice vyústil v zajímavou diskusi, kterou dokumentuje kniha Defending the Earth, ale pro Naesse nebyl ničím významným. Stručně rečeno, Bookchinova kritika hlubinnou ekologii naessovské provenience nepromění. Naopak sborník "Myslet jako hora" z roku 1988 jednoznačně potvrdí nastolený směr. Bookchin na zmíněné konferenci kritizoval hlubinněekologický misantropismus a anti-humanismus, projevující se mimo jiné v článcích oslavujících AIDS, jaderné války a v článcích propagující omezení obyvatel na 100000 000, protože to sice přinese jisté utrpení, jenže kvalita života oněch 100000000 toto utrpení nahradí.

${ }^{26} \vee$ této souvislosti je mimořádně zajímavé, že Naess se o pro environmentální hnutí naprosto zásadní knize Rachel Carsonové dozvěděl až v roce 1967 - tedy dávno poté, co zformuloval své vlastní postoje.

${ }^{27}$ Naess sám to implicitně přiznává nejen ve svém životopisu, ale též ve většině zásadních článků. Viz např. Naess, A. Ztotožnění jako zdroj hlubinných ekologických postojů. In Závod s časem. Texty z morální ekologie. Vyd. 1. Praha : Torst 1996, s. 100-101.

28 Viz Naess, A. Sebeuskutečnění: ekologický přístup k bytí ve světě. In Myslet jako hora: Shromáždění všech bytostí. Vyd. 1. Prešov : Abies, 1993. s. 33.

${ }^{29}$ Viz Naess, A. Deep Ecology in the Line of Fire. The Trumpeter, 1995, roč. 12, č. 3.

30 Viz Naess, A. Ztotožnění jako zdroj hlubinných ekologických postojü. In Závod sčasem. Texty z morální ekologie. Praha : Torst 1996, s. 86; či Naess, A. Sebeuskutečnění: ekologický přístup k bytí ve světě. In Myslet jako hora: Shromáždění všech bytostí. Prešov : Abies 1993 s. 30-31. 
Gándhí nás Naess nezpravuje o tom, jak přesně k tomuto rozšiřování dochází - kromě náznaků a odkazů na další autory nalezneme spíše velmi vágní, nicméně emocionálně pưsobivé pasáže, ale hned v několika textech nás ujištuje o tom, že se jedná o proces ontologický, nikoliv psychologický. Tento proces Naees označuje jako ztotožnění, identifikaci. Ztotožnění, které jako mimoracionální proces vede k zániku rozdílu mezi ego a alter. ${ }^{31}$ Navíc - pokud nezưstaneme u pouhých mimoracionálních dojmů - vede toto pojetí ke zřejmým rozporům, řešitelným pouze dalším důrazem na mimo- a iracionalitu. (Jako př́klad Ize uvést Naessovo nahrazení altruismu péčí o sebe sama - je-li Já všude, jak je možné, že existují reálné rozdíly v možnosti ovlivňovat Já? Jak je možné, že „přirozeně" dáváme přednost některým částem Já před jinými, jaké je postavení já v Já? Jak se mé Já s velkým J liší od tvého Já s velkým J, pokud obě zahrnují vše?) Pouze ztotožněním můžeme dosáhnout sebe-realizace, velké jednoty, konečného splynutí. $K$ tomu je však potřeba ještě změny gnoseologické. Tento v Naessově díle spíše okrajový - významem však centrální - bod, později hojně zneužívaný radikálními hlubinnými ekology, můžeme popsat následujícím způsobem. Jde o zahrnutí a nadřazení pocitového, emocionálního, do či spíše nad náš poznávací a hodnotící proces a neprímo též pokus o - samozřejmě dnes již fakticky nemožnou - rehabilitaci mýtu. ${ }^{32} \mathrm{~V}$ tuto chvíli přeskočím Naessovu konkretizaci tohoto schématu $v$ tzv. gestaltech a přiblížím přímo samu ideu. Podle Naesse je rozpor mezi ochranářem, který hovoří o nedotknutelném „srdci lesa" a těžebním dělníkem, který tomuto pojmu nerozumí, nikoliv v etickém hodnocení, ale v ontologii a gnozeologii. Abstraktní celky jako „život řeky”, „srdce lesa”, „ticho jezera" pro ochránce přírody existují stejně pevně a nezpochybnitelně jako pro těžebního dělníka buldozer. ${ }^{33}$ Poznává je se stejnou zřejmostí, přiřazuje jim podobně významnou hodnotu. Tyto celky jsou reálně, ontologicky stejně významné jako ony. Pocitové a emocionální vlastnosti nejsou součástí subjektu, ale existují objektivně, jako součásti jistých abstraktních celků a konečně jako Já. Proto je jejich zahrnutí do průběhu našeho poznávání naprosto zásadní. Hodnotu lesa určíme vcítěním, ztotožněním se, rozplynutím. Vcítěním se poznáváme objektivně, objektivněji než vědeckým poznáním.

Z hlediska ontologických východisek je tedy Naess velmi podobný Gándhímu. ${ }^{34}$ Také on - ačkoliv paradoxně protestuje proti dosavadnímu evropskému dualismu - rozděluje svět na svět skutečného Já - zahrnující mu celý vesmír a skutečně existující - a svět já, který je nejen nesmírně omezený, ale též ontologicky neobhajitelný. Stejně jako Gándhí transformuje hodnoty vzhledem k jinému než tomuto světu a vytváŕí tak místy až doslova fantaskní konstrukce. A stejně jako Gándhí logicky konzistentně - jak laskavý čtenář uvidí v další části - přenáší tuto ontologickou představu do svého pojetí gnozeologie a etiky. Hlavní - a z mého pohledu nesmírně závažný - rozdíl spočívá v uznání jistých konsekvencí tohoto postoje. Naess je bytostně neschopen Tolstého, Gándhího či Heideggerova antiindividualistického postoje. Téměř $v$ každém díle vyzývá čtenáře $\mathrm{k}$ hledání vlastních koncepcí, k tvorbě originální filosofie, kritice „absolutních" pravd - a je přitom upř́mný. Navíc je vždy ochoten od předem vytvořené logické konzistence odstoupit, je ochoten udělat úkrok směrem od jediné, pravé pravdy a toho není v hlubinné ekologii schopen

31 Viz studie Několik kritických poznámek k „hlubinné ekologii” Arne Naesse. Binka, B. Několik kritických poznámek k "hlubinné ekologii" Arne Naesse. Universitas, 1999, č. 4, s. 43-47.

32 Viz např. Naess. A. Mountains and Mythology. The Trumpeter, 1995, roč. 12, č. 4. Tento článek je nepř́mým odkazem na Seedův, Macyové a Flemingové sborník, do kterého Naess také přispěl. Naess ví, že návrat k mýtickému světu je bezpředmětný, nicméně pokusem o rehabilitaci jistých prvků mýtického světa tento článek je.

33 Tento př́klad je stručným výkladem zásadní pasáže Naessovy knihy Ecology, Community and Lifestyle: Outline of an Ecosophy. Viz Naess, A. Ecology, Community and Lifestyle: Outline of an Ecosophy. Cambridge, Syndicate of Press of the University of Cambridge 1989.

34 Této podobnosti si všimlo více autorů. Velmi dobrou studii o vztahu Naesse, Gándhího a Heideggera nalezne čtenáŕ v knize Contesting Earth's Future: Radical Ecology and Postmodernity. Viz. Zimmerman, M. E. Contesting Earth's Future: Radical Ecology and Postmodernity. Los Angeles, University of California 1994, s. 91-150. 
téměř nikdo jiný. Proto je Naess, ač zakladatelem, zároveň prvním a s velkou pravděpodobnostní též posledním disidentem hlubinné ekologie.

Pokračování př̌ště

\section{Literatura}

- Arnold, R., \& Free Congress Research and Education Foundation, (1982). At the eye of the storm: James Watt and the environmentalists. Chicago: Regnery Gateway.

- $\quad$ Beckmann, P. (1973). . : Press.

- $\quad$ Binka, B. (1999). . , 4, 43-47.

- $\quad$ Deep ecology Edited by M Tobias San Diego Avant Books, (1985). . San Diego: Avant Books.

- $\quad$ Devall, B. (1988). . : Smith Books.

- Devall, B., \& Sessions, G. (1985). . Salt Lake City: Peregrine Smith Books.

- $\quad$ Drengson, A. (1995). ., 12(3), 832-6193.

- Fox, W. (1992). Arne Naess : A Biographical Sketch. The Trumpeter, 9(2), 832-6193.

- Langlais, R. (1995). . : Boston : Shambhala, ISBN.

- Librová, H. (1994). Pestř́ a zelení : Kapitoly o dobrovolné skromnosti. Brno: Veronica.

- Manes, Ch., (1990). Green Rage : Radial Environmentalism and the Unmaking of Civilization. Boston: Little, Brown and Copany.

- Naess, A. (1984). A Defense of the Deep Ecology Movement. Environmental Ethics, 6(3), 265-270.

- Naess, A. (1988). Deep Ecology and Ultimate Premisis. The Ecologist, 18(4/5), 128-131.

- Naess, A. (1995). Deep Ecology in the Line of Fire. The Trumpeter, 12(3), 832-6193.

- Naess, A. (1989). Ecology, Community and Lifestyle. Cambridge: Syndicate of Press of the University of Cambridge.

- Naess, A. (1974). Gándhí and Groupe Conflict : An Exploration of Satyagraha - Theoretical Background. Oslo: Universitetsforlaget.

- Naess, A. (1965). Gándhí and the Nuclear Age. Totowa: Bedminister.

- Naess, A. (1997). Heidegger, Postmodern Theory and Deep Ecology. The Trumpeter, 14(4), 832-6193.

- $\quad$ Naess, A. (1993). How Should Supporters of the Deep Ecology Movement Behave in Order to Affect Society and Culture. The Trumpeter, 10(3), 832-6193.

- Naess, A. (1984). Intristic Value, and Deep Ekology : Comments on an Article by Warwick Fox. The Ecologist, 14(5/6), 261-3131.

- Naess, A. (2001). Legend, Deprived And Also College Students. The Trumpeter, 13(1), 8326193. 
- Naess, A. (1993). Sebeuskutečnění : ekologický prístup k bytí ve světě. Myslet jako hora : Shromáždění všech bytostí, 80-88699.

- Naess, A. (1989). The Deepness of Deep Ecology. Earth First! : The Radical Environmental Journal, 10(2), 7-8411.

- Naess, A. (2005). The Selected Works of Arne Naess. Dordrecht: Springer.

- $\quad$ Naess, A. (1992). The Three Great Movements. The Trumpeter, 9(3), 832-6193.

- Naess, A. (1985). The World of Concrete Contents. Inquiry, 28, 417-428.

- Naess, A. (1996). Ztotožnění jako zdroj hlubinných ekologických postojů. Závod s časem : Texty z morální ekologie, 100-101.

- Naess, A., \& Rothenberg, D. (1993). Is It Painful to Think? : Conversations with Arne Naess. London: University of Minnesota Press.

- $\quad$ Naess, A. (1995). Mountains and Mythology. The Trumpeter, 12(4), 832-6193.

- Seed, J. (1993) Uslyšet v sobě hlas plačící Země. In Myslet jako hora : Shromáždění všech bytostí (pp. 80-88699). Praha: Abies.

- Seed, J., Macy, J., Fleming, P., Naess, (1988). Thinking Like a Mountain : Towards a Council of all Beings. Philadelphia: New Society Publisher.

- Sessions, G. (1995) Ecocentrism and the Antropocentric Detour. In Deep Ecology for the 21st Century : Reading on the Philosophy and the Practice of New Environmentalism (pp. 1-570). Boston: Shambala.

- Skolimowski, H. (1992). Living Philosophy : Eco-Philosophy as a Tree of Life. London: Arkana.

- Zimmerman, M. E. (1994). Contesting earth's future: Radical ecology and postmodernity. Berkeley: University of California Press. 
Časopis Envigogika vydává Centrum pro otázky životního prostředí UK. Vývoj časopisu je podpořen projektem OP VK Mezioborová sít udržitelného rozvoje.

Více najdete na internetových stránkách projektu mosur.czp.cuni.cz
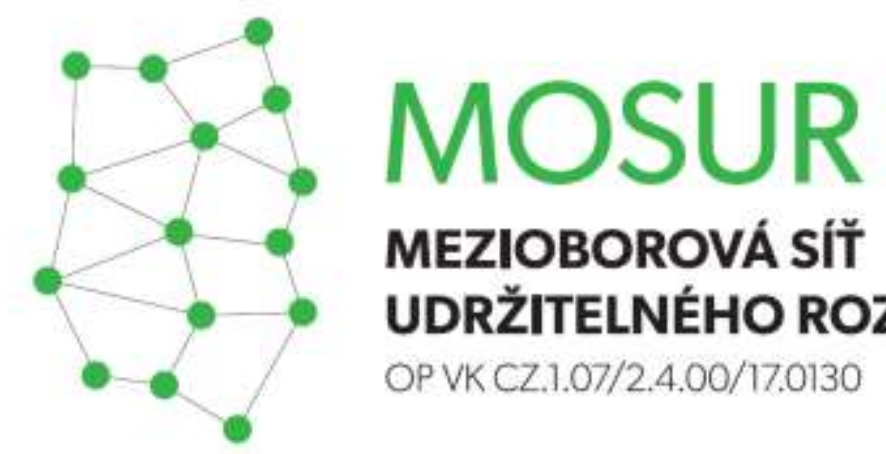

\section{MEZIOBOROVÁ SÍT} UDRŽITELNÉHO ROZVOJE

OP VK CZ.1.07/2.4.00/17.0130
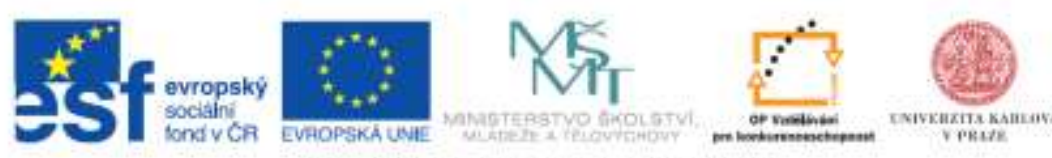

INVESTICE DO ROZVOJE VZDELAVANI 